https://doi.org/10.31470/2706-7904-2021-16-92-96

\title{
UNDERSTANDING BY STUDENTS OF INTERNET TEXTS IN THE SITUATION OF COVID-19 IN UKRAINE
}

Розуміння студентами інтернет-текстів у ситуації Ковід-19 в Украӥні

\section{Ernest Ivashkevych}

Ph.D. in Psychology, Professor's Assistant Rivne State University of the Humanities (Ukraine)

ivashkevych.ee@gmail.com https://orcid.org/0000-0001-7219-1086

\author{
Alexander Nabochuk \\ Ph.D. in Psychology, Doctoral Student \\ Hryhorii Skovoroda University in Pereiaslav (Ukraine) \\ nab_ol@ukr.net \\ https://orcid.org/0000-0002-1448-7687
}

\begin{abstract}
In the article we determined four main psychological peculiarities of understanding by students Internet texts. These peculiarities are: (1) understanding the Internet text by its contextuality, the predictors of which are: reality, versatility, paradigm, descriptiveness, deepness, subjectiveness and personally centered qualities; (2) understanding the Internet text by its psychological context, which includes such predictors, as: psychological justification, compressiveness, interest, entertaining, satisfaction, harmoniousness, emotiveness, expressiveness; (3) understanding the Internet text by its emotional context and predictors, such as: comfort, stylistic expressiveness, convenience, expressiveness, lightness, colloquial features, journalistic style of writing; (4) understanding the Internet text by its multifaceted paradigm, which is characterized by such predictors: paradigmatic, space, being updated, its stimulating, dialogic content, comfort characteristics of perceiving, frivolousness.
\end{abstract}

Key words: Internet text, understanding, psychological peculiarities of understanding, predictors of understanding, contextuality, psychological context.

\section{Introduction}

Bcmyn

In the conditions of COVID-19 contemporary Internet and communicative system are relatively new areas of human activity that are developing rapidly (Lawson \& Leck, 2006). 
There are not a lot of researches of the person's current online behavior, although this topic attracts the attention of researchers from many scientific and interdisciplinary fields. Accordingly, it is important to study the psychological nature of Internet communication as computer-mediated processes. After all, the multidimensionality of virtual communication has led to the fact that the Internet has created new configurations of classical measurements of the communicative process (Amichai-Hamburger, 2005).

So, the purpose of the article is to show psychological peculiarities of understanding by students Internet texts and to determine the predictors of such understanding.

\section{Methods and Techniques of the Research Методи і процедури дослідження}

The empirical methods of our research are: (1) the author's questionnaire to determine the goals of interpersonal communication in the Internet space (Nabochuk, 2020); (2) the questionnaire (Shkuratova, 2019), which has the aim to determine the motives of direct and indirect interpersonal communication; (3) the questionnaire with the purpose to provide diagnostics of interpersonal relationships by $\mathrm{T}$. Leary (The questionnaire of diagnostics of interpersonal relationships, 2018). The methods of math analysis and statistical data processing there were: content analysis, T-criterion of Wilcoxon, U-criterion of Mann-Whitney, factor analysis, semantic differential method.

The characteristics of the sample in our research: the students of Rivne State University of the Humanities and of Lesia Ukrainka Eastern European National University were participated. These students were of age 17-24, they regularly and actively have used the Internet to communicate $(n=376$ people, including 152 students of the faculties of humanities (34 boys and 118 girls). 129 students have studied at of technical specialties (80 boys and 49 girls), 31 of them were participants of the students' Internet forum (14 boys and 19 girls), 64 participants have formed a group which has participated in a specially organized extracurricular communicative process in the form of discussion of various topics (30 boys and 34 girls).

\section{Results}

Результати

The research of the goals of interpersonal communication of students in the Internet space, which was carried out by a specially designed questionnaire (Nabochuk, 2020), showed that all seven research goals (to make contacts, to provide understanding, information, the emotional goal, the purposes of coordination, motivation, relationships), 
which are characterized of both direct and indirect process of Internet communication. However, they have different levels of manifestation (Table 1).

\section{Table 1}

The objectives of direct and Internet mediated interpersonal communication of students

\begin{tabular}{lll}
\hline $\begin{array}{l}\text { The level } \\
\text { of manifestation }\end{array}$ & $\begin{array}{l}\text { Immediate } \\
\text { communication }\end{array}$ & $\begin{array}{l}\text { Mediation in } \\
\text { Internet communication }\end{array}$ \\
\hline High & $\begin{array}{l}\text { contact } \\
\text { understanding }\end{array}$ & informational \\
\hline Average & $\begin{array}{l}\text { informational } \\
\text { emotional } \\
\text { coordination }\end{array}$ & $\begin{array}{l}\text { contact } \\
\text { understanding }\end{array}$ \\
\hline Low & motivating \\
& installation of the relationships & $\begin{array}{l}\text { emotional, contact } \\
\text { coordination } \\
\text { relationships establishing } \\
\text { motivating }\end{array}$ \\
\hline
\end{tabular}

Qualitative interpretation of the obtained data shows that students underlined the main goals of direct communication as the aims of establishing contacts $(\mathrm{T}=10,744$, $\mathrm{p} \leq 0,01)$ and provide the whole understanding $(\mathrm{T}=-7,324, \mathrm{p} \leq 0,01)$, and the goal which was seen as the one which has been in a great degree Internet-mediated, such as informational purpose $(T=-6,960, p \leq 0,01)$. In both direct and Internet-mediated communication, students are reluctant to stimulate the partner's activity to perform certain actions (to motivate), as well as to fix their place in the system of role and status connections (to establish relationships). In such a way we have to note that the goals of communication which are Internet-mediated, to a lesser extent than direct, are the means of arising the emotional experience of the partner (emotional goal: $\mathrm{T}=-9,750, \mathrm{p} \leq 0,01$ ), mutual orientation, coherence of actions (coordination goal: $\mathrm{T}=-7,397, \mathrm{p} \leq 0,01$ ).

The analysis of the results of our research of the main types of interpersonal relationships by three measures of severity (by using the questionnaire by T. Leary (The questionnaire of diagnostics of interpersonal relationships, 2018)) is presented by Fig. 1. The results of the research show that the average indicators of different types of relationships in a case of direct and Internet-mediated communication of students are in the range of minimum and average values, and in the Internet environment with all types of interpersonal relationships, which are more less pronounced than in the process of direct communication. This indicates the psychological health and adequacy of most the subjects, as well as indicates the features of the Internet environment, which allows the students to build more constructive relationships in the process of communication. 


\section{Figure 1 \\ The average value of types of interpersonal relationships in direct and Internet-mediated communication of students}

The average value of types of interpersonal relationships in direct and Internet-mediated communication of students

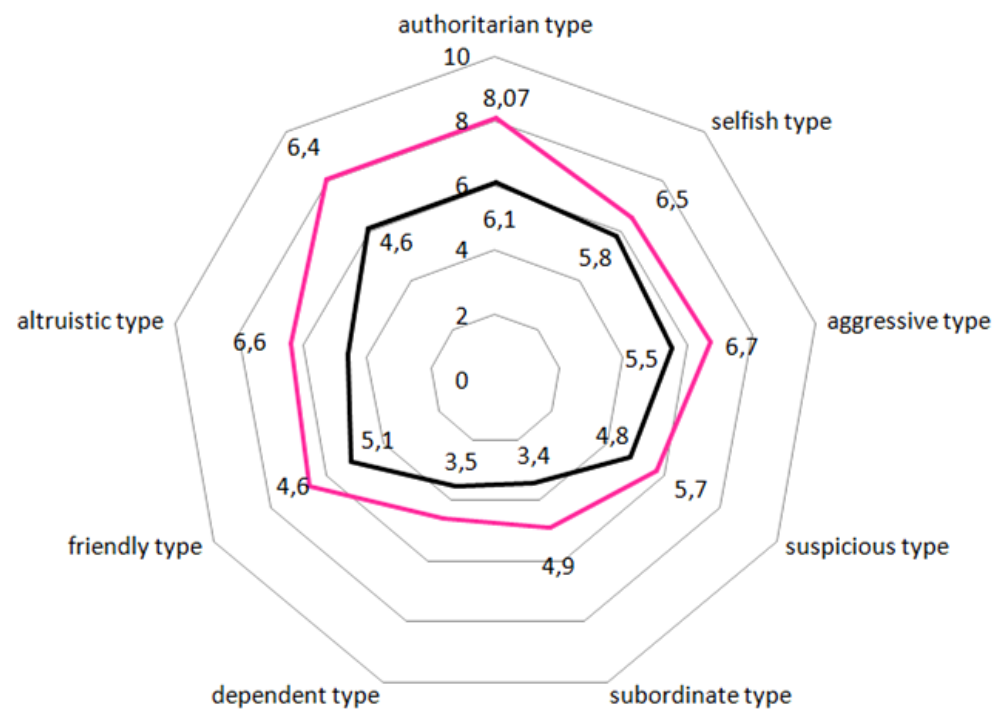

—Direct communication - Internet-mediated communication

Here is the example of a fragment of the protocol of one of the students:

"COVID-19: Anti-crisis law was published", "Healthy lifestyle: Fundamentals and Principles" - health is the highest value in our life;

"The main environmental problems of Ukraine", "The System of Education in Ukraine" - contemporary problems of Ukrainian society;

"COVID-19: Anti-crisis law was published", "The System of Education in Ukraine" - the organization of the educational system in Ukraine in the conditions of a pandemic;

"Healthy lifestyle: Fundamentals and Principles", "The main environmental problems of Ukraine" - a dialogue between the Self and the Environment - the aim of the formation of a single eco-organism;

"COVID-19: Anti-crisis law was published", "The main environmental problems of Ukraine" - problems of the world ecosystem in the conditions of a pandemic;

"Healthy lifestyle: Fundamentals and Principles", "The System of Education in Ukraine" - psychological determinants of a healthy lifestyle, having been laid down in the paradigm of educational system of Ukraine. 


\section{Conclusions}

Висновки

According to the results of our research, we determined four main psychological peculiarities of understanding by students the Internet texts in the situation of COVID-19.

These peculiarities are:

(1). Understanding the Internet text by its contextuality, the predictors of which are: reality, versatility, paradigm, descriptiveness, deepness, subjectiveness and personally centered qualities.

(2). Understanding the Internet text by its psychological context, which includes such predictors, as: psychological justification, compressiveness, interest, entertaining, satisfaction, harmoniousness, emotiveness, expressiveness.

(3). Understanding the Internet text by its emotional context and predictors, such as: comfort, stylistic expressiveness, convenience, expressiveness, lightness, colloquial features, journalistic style of writing.

(4). Understanding the Internet text by its multifaceted paradigm, which is characterized by such predictors: paradigmatic, space, being updated, its stimulating, dialogic content, comfort characteristics of perceiving, frivolousness.

The perspective of further researches is to increase in a great degree the opportunities for professional and personal development of students through Internet-mediated communication.

\section{References \\ Лimepamypa}

Amichai-Hamburger, Y. (2005). The social net: Understanding human behavior in cyberspace. Oxford, UK: Oxford University Press.

Lawson, H.M., \& Leck, K. (2006). Dynamics of Internet dating. Social Science Computer Review, 24(2), 189-208. https://doi.org/10.1177/0894439305283402

Metodyka diahnostyky mizhosobystisnykh stosunkiv T. Liri [The questionnaire of diagnostics of interpersonal relationships] (2018). Retrieved from http://www.psuhologia.in.ua/images/dustan/ispl1.pdf [in Ukrainian].

Nabochuk, O. (2020). Opytuvalnyk vyznachennia tsilei mizhosobystisnoho spilkuvannia v Internetprostori [The questionnaire to determine the goals of interpersonal communication in the Internet space]. Rivne: Rivne State University of the Humanities [in Ukrainian].

Shkuratova, I.P. (2019). Metodyka vyznachennia motyviv bezposerednoho i oposeredkovanoho mizhosobystisnoho spilkuvannia [The questionnaire: Motives of direct and indirect interpersonal communication]. Retrieved from http://dspace.pnpu.edu.ua/bitstream [in Ukrainian]. 